\title{
WCCM-ECCOMAS 2020 - 5139 - THERMAL ANALYSIS OF A METAL STRUCTURE USING THE ANSYS SOFTWARE
}

\author{
Paiva, E. M. ${ }^{1}$ and Anunciação Jr, N.C. ${ }^{2}$ \\ Av. das Castanheiras, s/n - Lote 3700 - Águas Claras, Brasília - DF, Brazil, 72025-065 \\ 1'memanuelp@gmail.com; 2engnjunior@gmail.com
}

Key Words: Metallic Structure, Thermal Analysis, Metal Alloy, Performance

\begin{abstract}
Metallic structures are an alternative in civil construction in terms of optimization of time and efficiency, about the construction process, besides being more versatile, durable, resistant and sustainable compared to other structures. Therefore, self-supporting metal towers have become indispensable in the expansion of large urban centers, due to the need for more slender, efficient and durable structures to the impacts caused by both man and the environment. However, its structures suffer daily from long sun exposure and contact with the atmosphere, which carries chemical elements that react with the material and cause pathologies such as thermal wear and chemical corrosion. Thus, the proposal of the work consists of analysing the behaviour and thermal performance of a metal tower with different metal alloys: ASTM A36, ASTM A570, and ASTM B338, thus determining density, capacity, and thermal conductivity. The model of the self-supporting tower used, is 36 meters high, opening the base of 15 meters, weighing throughout $209,730 \mathrm{~kg}$ and with a total of 1777 connecting elements distributed throughout the structure, shown in (Figure 1).
\end{abstract}
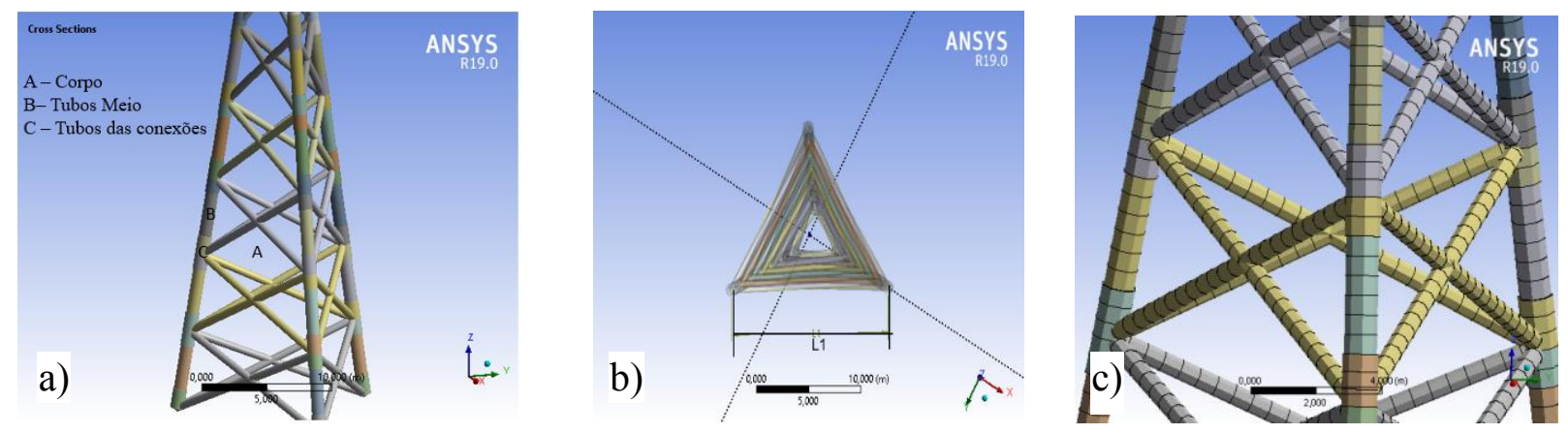

Figure 1 - Study model a) Tower structure, (b) opening of the base, c) tower connection elements.

To perform the analysis, ANSYS 19.0 software was used that calculated the performance of the materials at two different times, with higher solar incidences in the city of Brasília (10:00 AM and 4:00 PM), data verified by SOL-AR software 6.2. Afterward the analyses, it was verified that the thermal performance. Lastly was obtained the greatest results, of within material ASTM B338 obtained better results compared to materials A36 and A570, as exposed in (Figure 2), thus demonstrated to be more resistant to the effects of thermal wear and chemical corrosion.
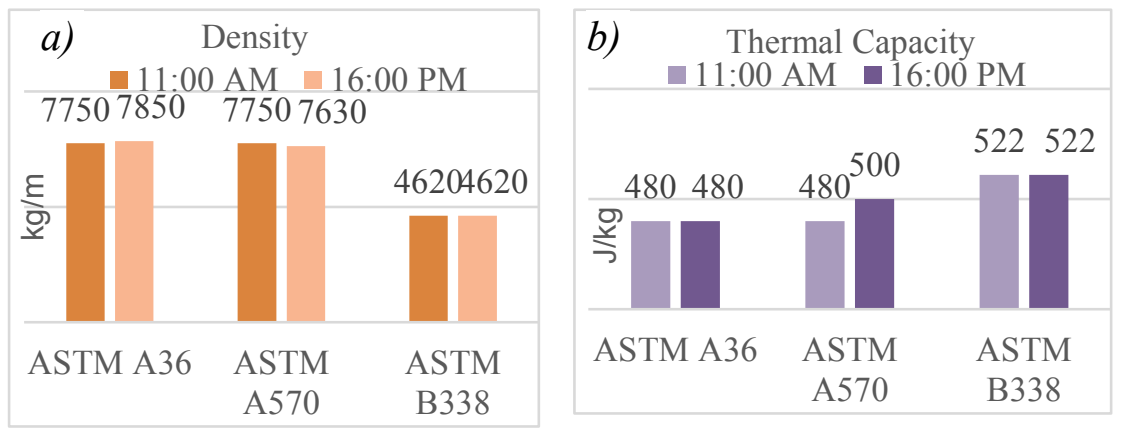

c) Condutividade Térmica
11:00 AM $16: 00 \mathrm{PM}$

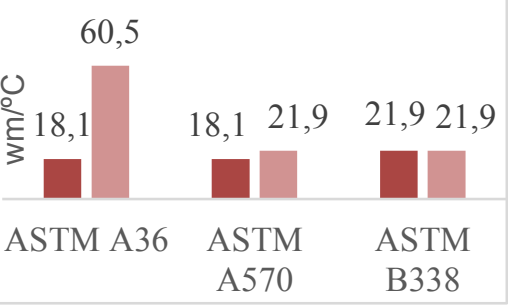


Paiva, E. M. Paiva, E. M. ${ }^{1}$ and Anunciação Jr, N.C. ${ }^{2}$

Figure 2 - Results in both hours analysed-(a) Density, (b) thermal capacity and (c) thermal conductivity

\section{INTRODUCTION}

Over the years, there has been an exponential increase in the telecommunications area, such as the spread of radio signal, with a large increase in telephone network coverage in urban and rural areas throughout the country.

With the need for the expansion of radio signal transmission, the implementations of metal towers have gained enhancement in the urban environment, because they are very slender structures, which allow to be sized in order to accept the support of the antennas in the appropriate height and position. However, in view of the need for each location, as towers can have different configurations, always seeking efficiency, through low cost and compliance with security conditions. Through the years that have elapsed, it became necessary to have more durable structures with higher heights, so concrete towers have been replaced by steel structures (REZENDE, FELIPE, 2012). Most of the structural steel metal towers are very slender structures, sized to allow them to sustain weights, such as antennas, water box or high voltage cables. According to (BRASIL, SILVA, 2006), self-sustaining towers are subject to taking into account efforts caused by wind, only static effects. A poorly sized tower can suffer much more from wind, corrosion, material wear and high deformation rate at high temperatures. Thus, it is necessary to know the behaviour of the structure to be aware of the efforts it is subjected to and the lifetime, in order to make an appropriate project and perform maintenance appropriate such as thermal loads de can negatively impact years, with the use increasingly slender, effects of loading.

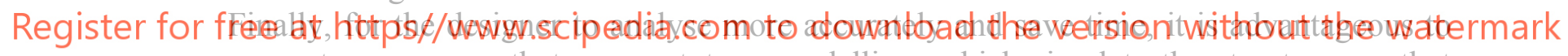
use computer programs that use prototype modelling, which simulate the structure, so that they are fully handleable. Thus, modelling and analysis software such as ANSYS, MENTOR GRAPHICS and Static Analysis (SAST) have gained space in the market because it is a reference in programs that can optimize the projection time of a structure to be built.

\section{MATERIAL AND METHODS}

For the materials will be highlighted four important characteristics for the software to perform the desired calculations. They are: Yield limit, which represents the maximum stress that the material can withstand without leaving its default state; Tensile strength, which is the maximum stress that a material can withstand without failing or breaking; Modulus of elasticity, mechanical property that measure the stiffness of the material; and finally, Poisson coefficient, relationship between relative transverse deformation and relative longitudinal deformation. 
ASTM A36 steel is categorized as a carbon steel of medium mechanical strength and with good weldability due to its small amounts of carbon. A downside to this material is its propensity to rust if there is no medium or high strength coating. The tube is commonly known as A36 steel (Figure 3). The material can be used in bridges, metal structures, walkways, oil rigs, among other applications. The composition of the material is described in (Table 1), where it is possible to describe the elements that make up the leaked tube, the density of the material and its respective coefficients necessary for the project
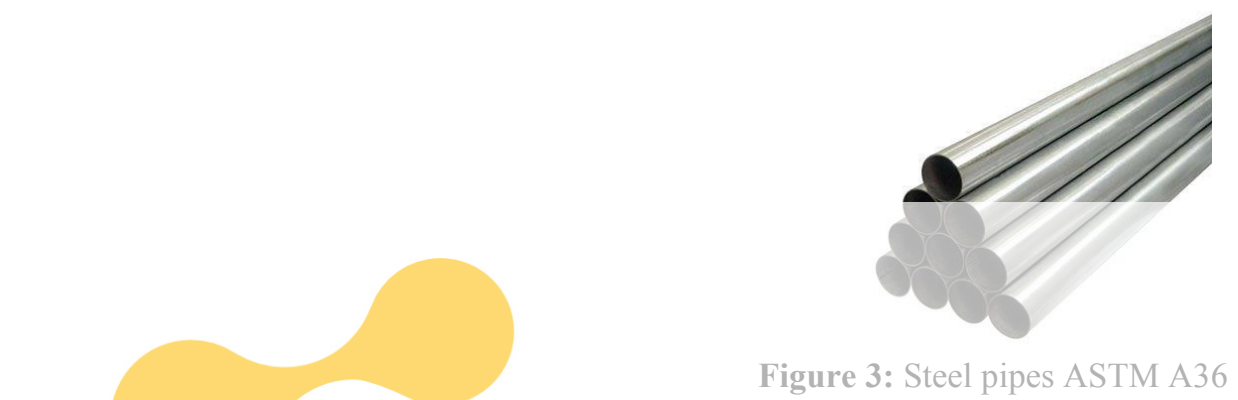

Table 1: Characteristics of ASTM A36 Steel Pipes

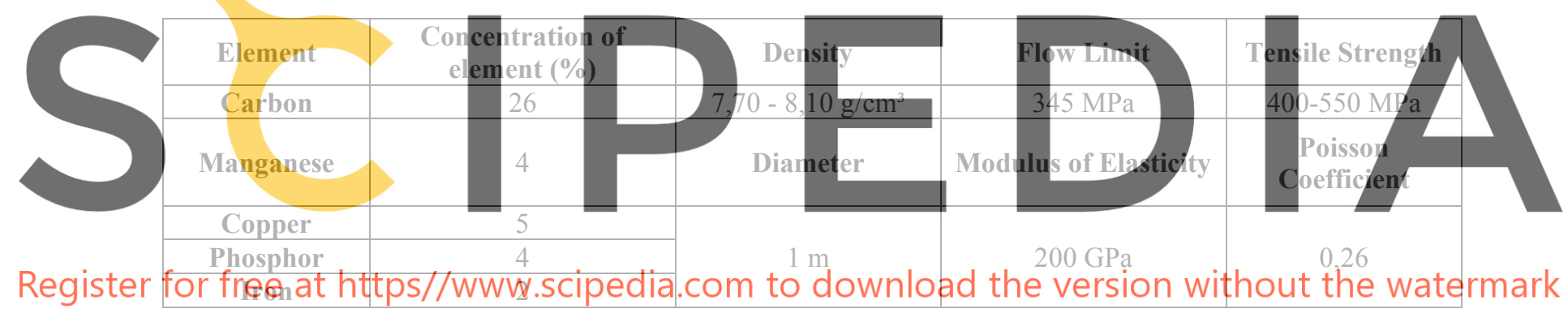

The ASTM A570 steel tube (Figure 4), is made of structural steel of low alloy and high strength, good tenacity and weldability. Steel pipes have good structural quality, in addition to the guarantee against chemical decomposition. Its characteristics are described in (Table 2).

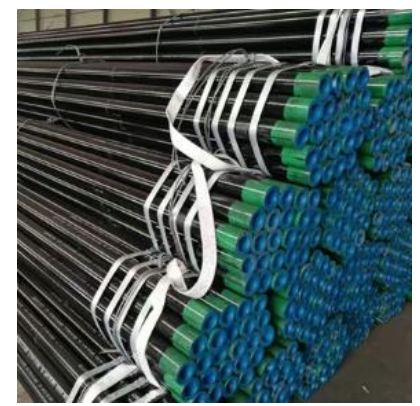

Figure 4: Steel Pipes ASTM A570 
Paiva, E. M. Paiva, E. M. ${ }^{1}$ and Anunciação Jr, N.C. ${ }^{2}$

Table 2: Characteristics of ASTM A570 Steel Pipes

\begin{tabular}{|c|c|c|c|c|}
\hline Element & $\begin{array}{c}\text { Concentration of } \\
\text { element (\%) }\end{array}$ & Density & Flow Limit & Tensile Strength \\
\hline Carbon & 25 & $7,70-8,10 \mathrm{~g} / \mathrm{cm}^{3}$ & $345 \mathrm{MPa}$ & $450 \mathrm{MPa}$ \\
\hline Manganese & 25 & Diameter & $\begin{array}{c}\text { Modulus of } \\
\text { Elasticity }\end{array}$ & $\begin{array}{c}\text { Poisson } \\
\text { Coefficient }\end{array}$ \\
\hline Copper & 20 & $1 \mathrm{~m}$ & $190-210 \mathrm{GPa}$ & $0,27-0,30$ \\
\hline Phosphor & 14 & 15 & & \\
\hline Iron & 15 & &
\end{tabular}

The titanium tube (Figure 5) has interesting properties compared to the Steel Tube A36 and ASTM A570, it has low density, good mechanical tensile strength and excellent corrosion resistance. Its thermal conductivity is low, as it corresponds to only $93 \%$ of the thermal conductivity of steel and $12.5 \%$ of the thermal conductivity of aluminium. Titanium also has a low linear thermal expansion coefficient, of the order of $64 \%$ of the linear thermal expansion coefficient of steel and $39 \%$ of aluminium. (Table 3) describes the other characteristics of the analysed tube.
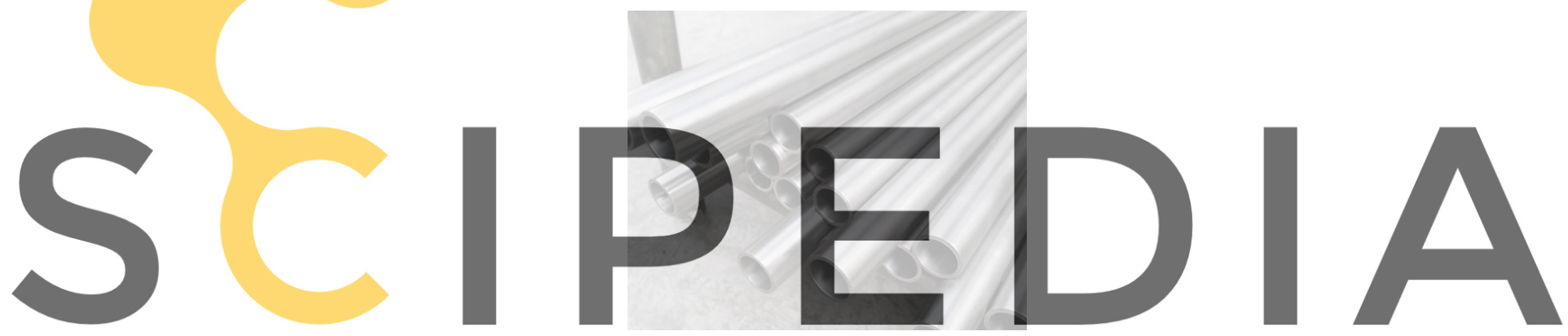

Figure 5: Titanium Tubes ASTM B338

Register for free at https//www.scipedia.com to download the version without the watermark

Table 3: Characteristics of ASTM B338 Titanium Tubes

\begin{tabular}{|c|c|c|c|c|}
\hline Element & $\begin{array}{l}\text { Concentration of } \\
\text { element }(\%)\end{array}$ & Density & Flow limit & Tensile strength \\
\hline Titanium & 99 & $4,50 \mathrm{~g} / \mathrm{cm}^{3}$ & $275 \mathrm{MPa}$ & $344 \mathrm{MPa}$ \\
\hline Copper & 0,25 & Diameter & $\begin{array}{l}\text { Modulus of } \\
\text { elasticity }\end{array}$ & $\begin{array}{l}\text { Poisson } \\
\text { Coefficient }\end{array}$ \\
\hline Iron & 0,30 & \multirow{3}{*}{$1 \mathrm{~m}$} & \multirow{3}{*}{$344 \mathrm{GPa}$} & \multirow{3}{*}{0,29} \\
\hline Oxygen & 0,30 & & & \\
\hline Carbon & 0,15 & & & \\
\hline
\end{tabular}

To start the development of the work, first, it is necessary a consistent characterization of the problem, modelling of the structure that is to be analysed, evaluation of what results one wishes to obtain, in order to be able to determine what information is available for the weighting of the input data. The characterization of a real problem consists in considering what are its effects, phenomena or quantities. 
For the design of the model, one must insert information that composes a metal structure tower, information that serves as input data. After that, it is necessary to define all the characteristics of the tower and port the model made in ANSYS: Mechanical APDL to the analysis tool ANSYS: Transient Thermal. After applying the tool, pre-define the three materials that will be used on the platform. Finally, rotate the analyses with the materials, compare the results between them and discuss which is the most viable in the imposed situation. The logical scheme of the work is shown in (Figure 6).

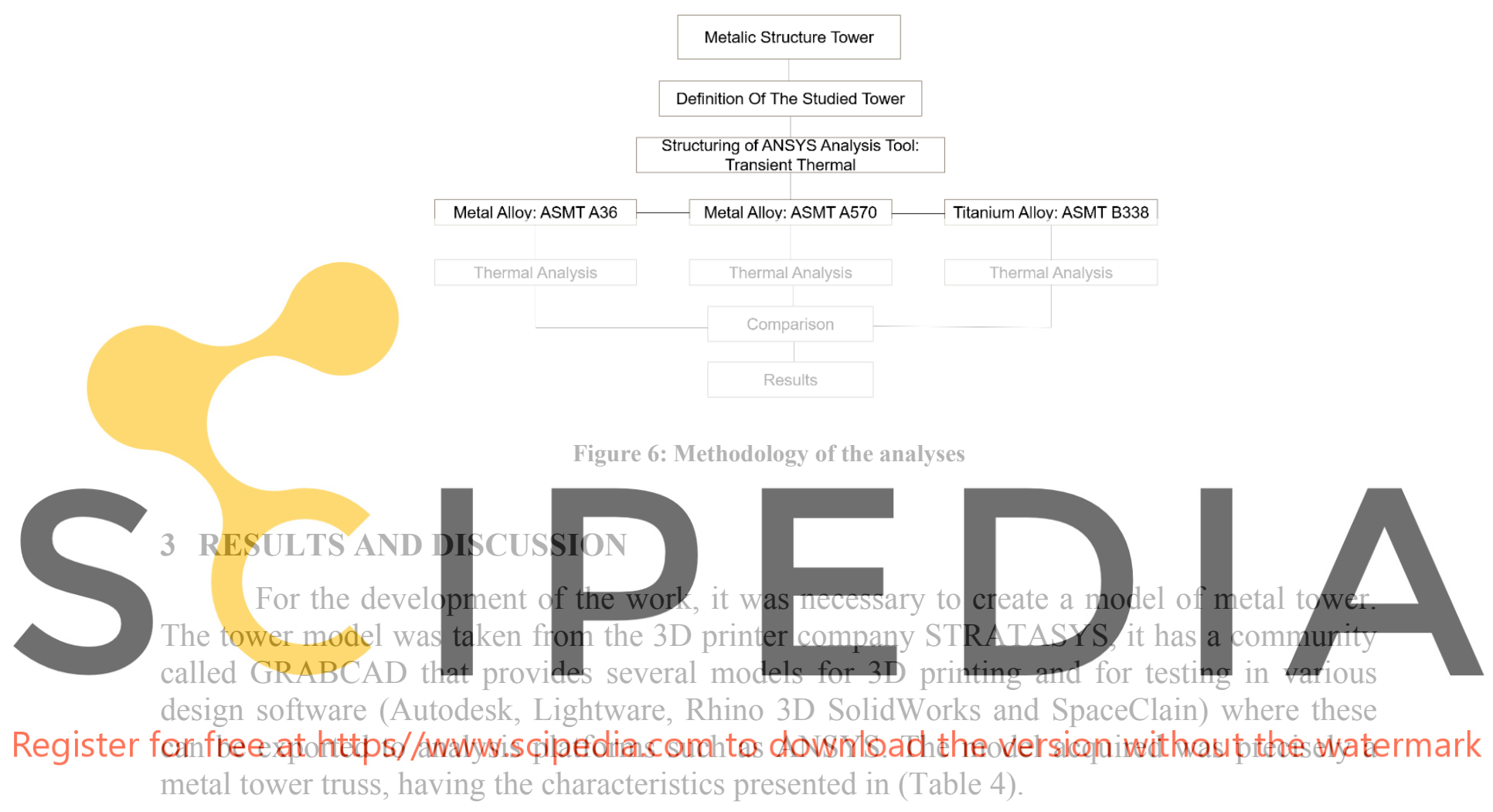

Table 4: General Information of the tower

\begin{tabular}{|l|l|l|l|}
\hline \multicolumn{3}{|c|}{ Measures } & \multicolumn{2}{c|}{ Properties } \\
\hline Length $\mathrm{x}$ & $13 \mathrm{~m}$ & Volume & $26,717 \mathrm{~m}^{3}$ \\
\hline Length $\mathrm{y}$ & $15, \mathrm{~m}$ & \multirow{2}{*}{ Mass } & $209.730 \mathrm{Kg}$ \\
\hline Length $\mathrm{z}$ & $36, \mathrm{~m}$ & & \\
\hline
\end{tabular}

For ANSYS to recognize the model as a whole, it is necessary to connect all key elements called edge split by the software. These elements are meeting points of the tubes that serve as a connection that connect one by one to the common parts, thus creating the connection between the elements (tubes and nodes) as demonstrated by (Figure. 7). 
Paiva, E. M. Paiva, E. M. ${ }^{1}$ and Anunciação Jr, N.C. ${ }^{2}$

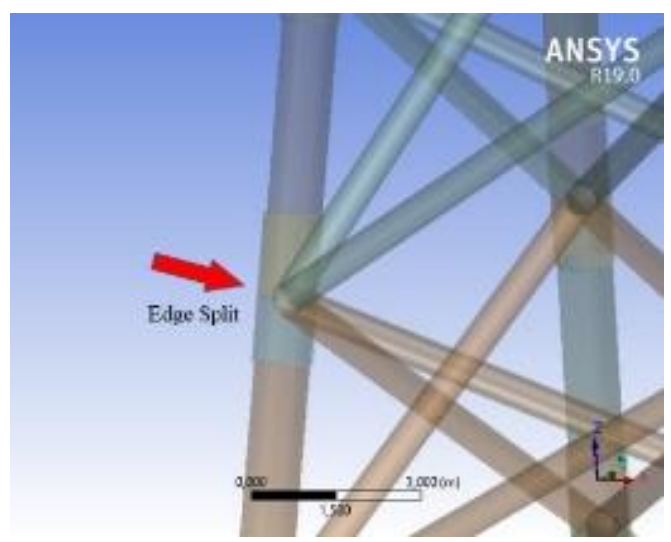

Figure 7: Edge Split

Each group has a number of different pipe elements and thicknesses. Group A is the main group because it constitutes the tower body. It has a total of 38 edges split (Figure 8), with an internal diameter of $0.28 \mathrm{~m}$ and an external diameter of $0.30 \mathrm{~m}$.
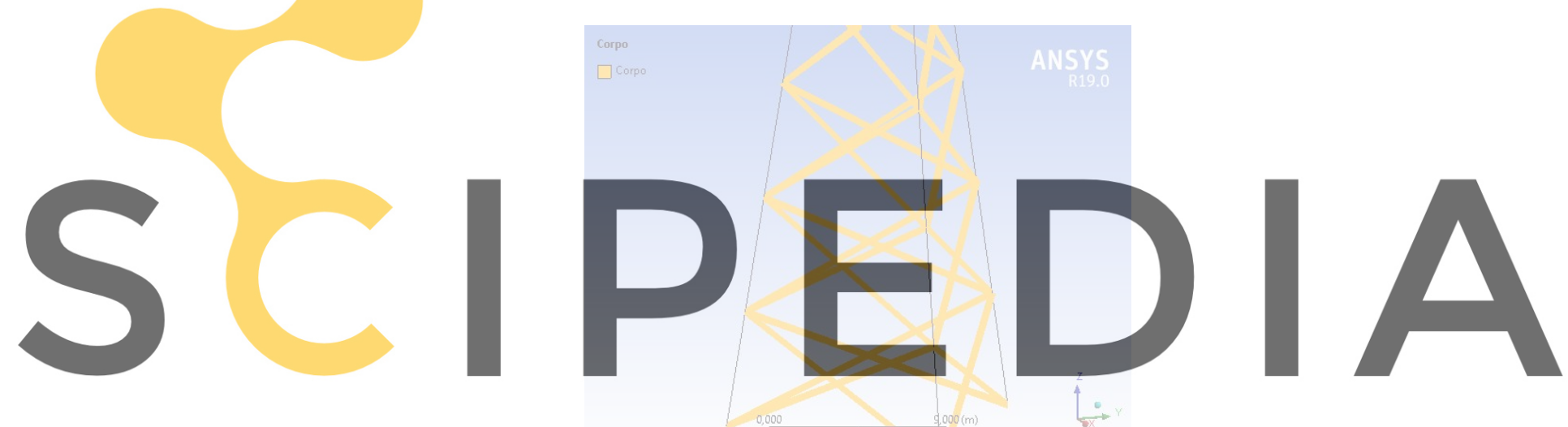

Register for free at https//www.scipedia.com to download the version without the watermark Figure 8: Group A

The group B tubes have the function of rounding up the group C tubes, thus forming the support columns of the tower. Group B has a total of 36 edges split (Figure 9), with an internal diameter of $0.48 \mathrm{~m}$ and an external diameter of $0.5 \mathrm{~m}$.

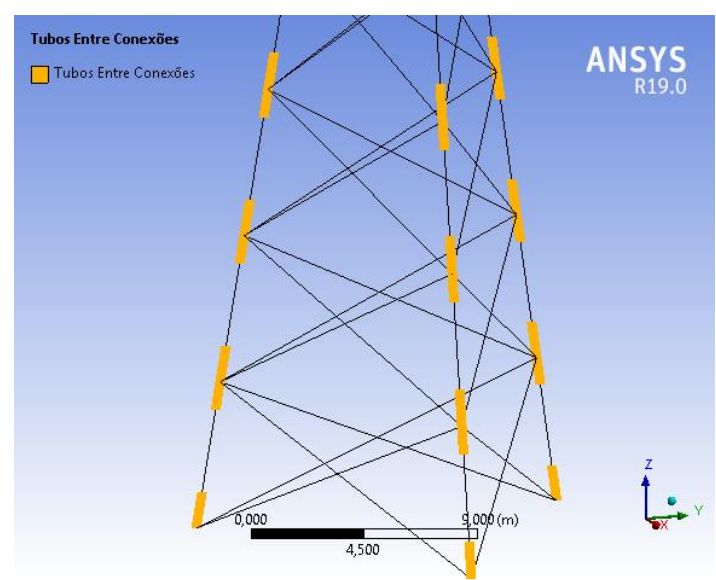

Figure 9: Group B 
Finally, the tubes of group $C$ are the support tubes that assist in the support of the tubes of group B, the group has the amount of 42 edges split (Figure 10), with an internal diameter of $0.50 \mathrm{~m}$ and an external diameter of $0.55 \mathrm{~m}$.

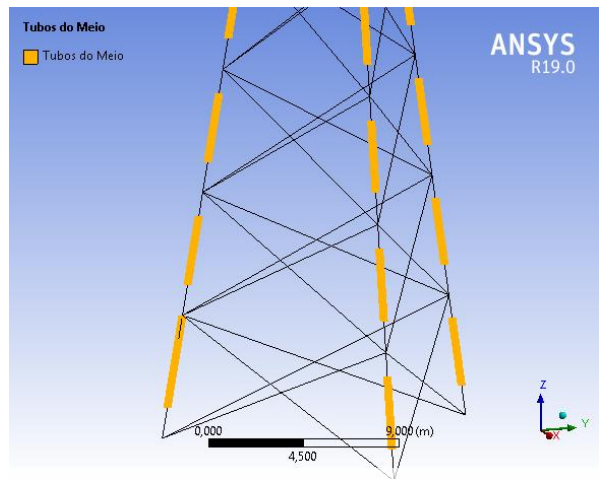

Figure 10: Group C

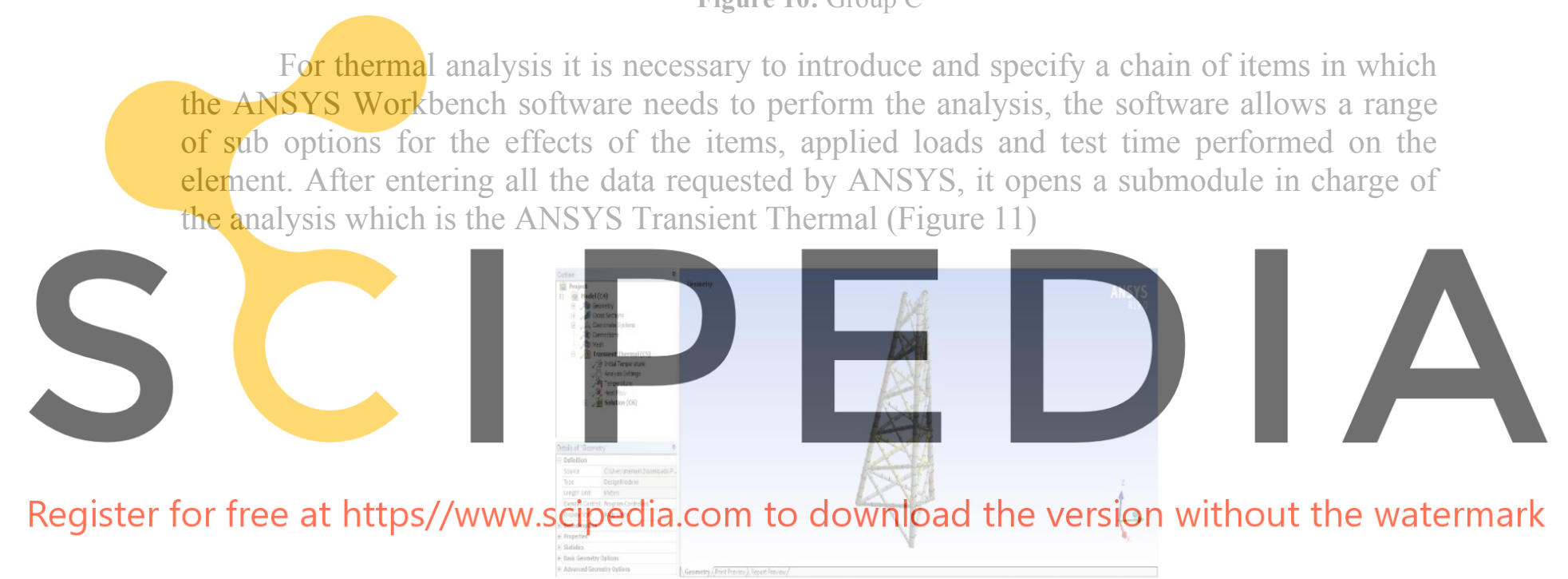

Figure 11 - ANSYS Transient Thermal Module Screen

The main elements that make up the ANSYS Transient Thermal software analysis tool were followed with a process tree where items are organized, as demonstrated by (Figure 12). The items are:
a. Project: Model being used;
b. Geometry: Components that structure the model;
c. Cross Sections: Are the groups that make up the model body;
d. Coordnate Systems: Geographical cordenas and ordering of the $\mathrm{x}, \mathrm{y}$ and $\mathrm{z}$ axes;
e. Mesh: Mesh generated by the software;
f. Transient Thermal: Section designated for the configuration of the chosen analysis. 
Paiva, E. M. Paiva, E. M. ${ }^{1}$ and Anunciação Jr, N.C. ${ }^{2}$

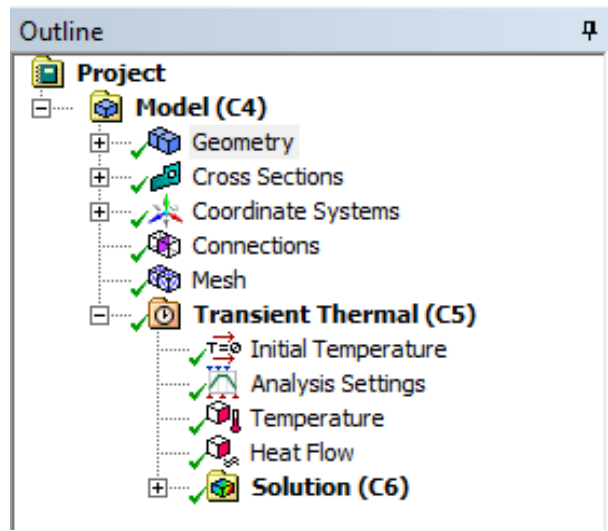

Figure 12: Simulation Detail

The next step in the configuration of thermal analysis was to establish the period in which the material will be exposed to the established temperature. The software presents the possibility of establishing the standard starting temperature and an optional second temperature, an option that will be the maximum temperature that the material can be subjected to without entering the melting point. Using the SOL-AR software it was possible to determine the times and positions with the highest solar incidences in Brasília/DF (Figure 13), determining the following times: 11:00 AM, 04:00 PM.After choosing the schedules, it is essential to determine the average ambient temperature of the chosen periods, they were: $27^{\circ}$

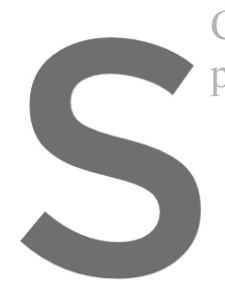
Celsius in the morning and platform (weather weather - D
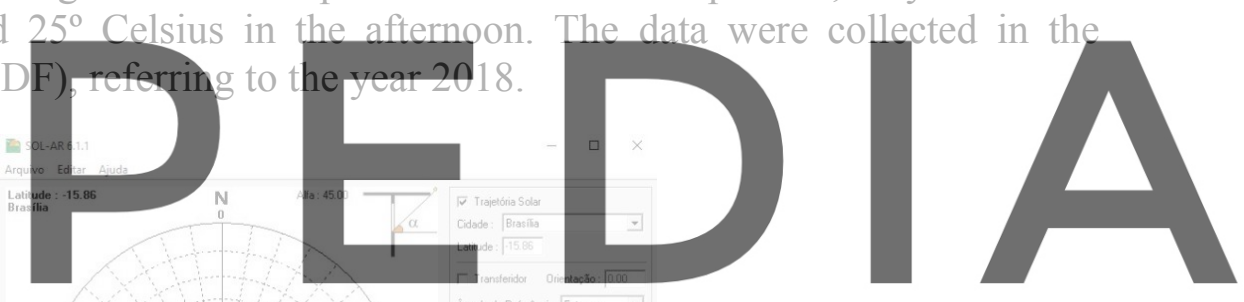

Register for free at https//www.scipedia.com to download the version without the watermark

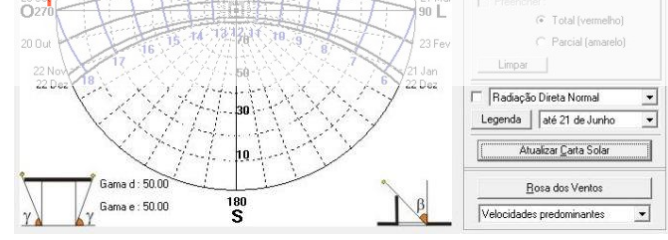

Figure 13: Solar chart of Brasilia/DF

Case 1: ASTM A56 steel pipe - After inserting the data mentioned in item 4.4 in the software, the next step was to analyse separately the behaviour of the tower with each material. The software calculates the exposure of the material in the periods determined in item 4.3.1.2 at a minimum and maximum temperature, thus checking the behaviour of the pipes by varying the two temperatures, thus highlighting the pipes according to the temperature that are currently reacting.

As seen in (Figure 14) and (Figure 15), ASTM A36 tubes, consisting mainly of carbon and other good heat-conducting metals, are likely to dissipate thermal load more easily. Fact observed by the tubes adjacent to the tubes of the exposed time. In the course of the images, it 
can be seen that the temperatures that the tubes can reach are: $41,902^{\circ} \mathrm{C}, 45,650{ }^{\circ} \mathrm{C}$ minimum and $1410{ }^{\circ} \mathrm{C}$ maximum in both hours.

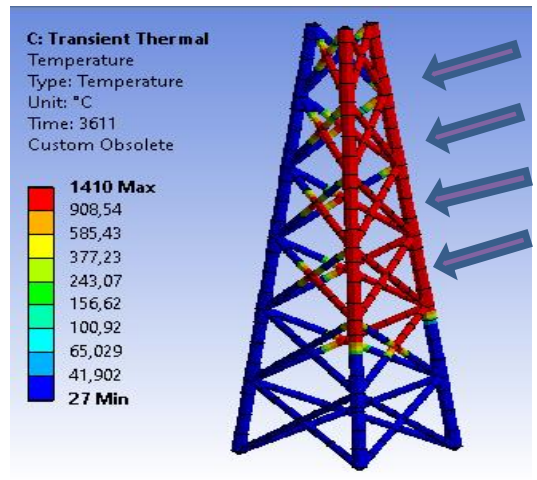

Figure 14: ASTM A36 tube exhibition at 11:00 AM
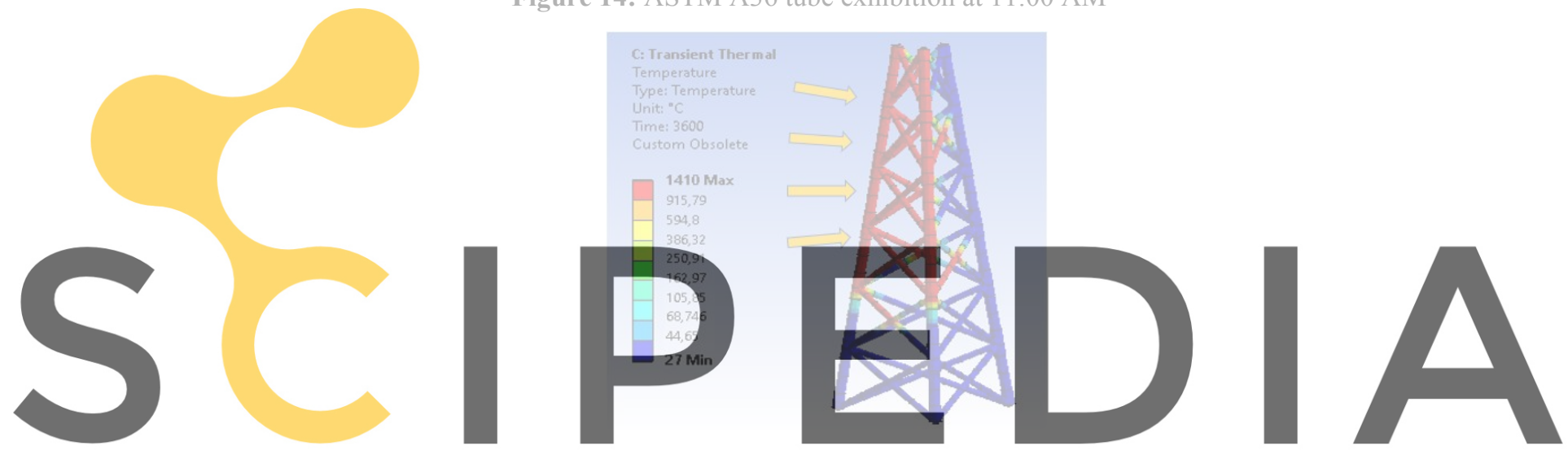

Register for free at https//www.scipedia.com to download the version without the watermark

Case 2: ASTM A570 steel pipes - As stated in the previous case, astm A570 carbon

steel tubes have behavior and values very similar to ASTM A36, where in the course of the analyses it was reported that thermal loads may vary between $42,222{ }^{\circ} \mathrm{C}, 40,376^{\circ} \mathrm{C}$ minimum and $1510^{\circ} \mathrm{C}$ maximum in both hours. In (Figure 16) and (Figure 17), it can be analyzed that even with values very close to the previous case, the propagations of thermal loads in the tubes are quite different.

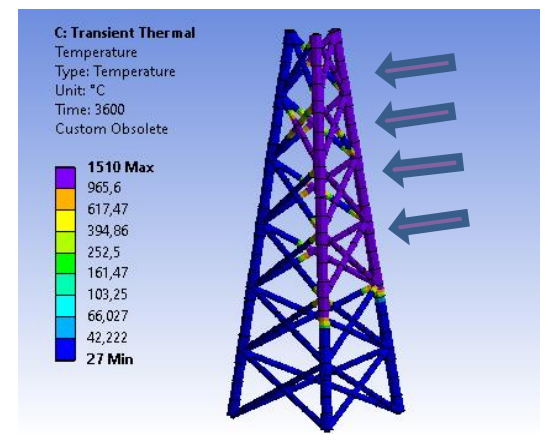

Figure 16: ASTM A570 tube exhibition at 11:00AM 
Paiva, E. M. Paiva, E. M. ${ }^{1}$ and Anunciação Jr, N.C. ${ }^{2}$

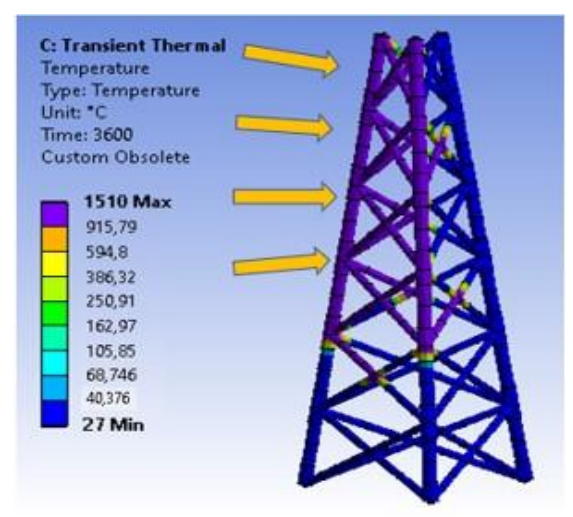

Figure 17: ASTM A570 tube exhibition ate 16:00 PM

Case 3: ASTM B338 titanium pipe - Finally, for case 3, titanium tubes were adopted, which has very different results from the others. Its thermal conductivity is low, as it corresponds to only $93 \%$ of the thermal conductivity of stainless steel and $12.5 \%$ of the thermal conductivity of aluminum as discussed by (N. P. TRIGUB, G. ZH. ZHUK, A. A, 2006. In the course of the images it can be seen that the temperatures that the tubes may reach are $42,692{ }^{\circ} \mathrm{C}, 44,650{ }^{\circ} \mathrm{C}$ minimum and $1668^{\circ} \mathrm{C}$ maximum. In (Figure 18) and (Figure 19) the dissipation of thermal loads were well accentuated from the tubes of group B and C.
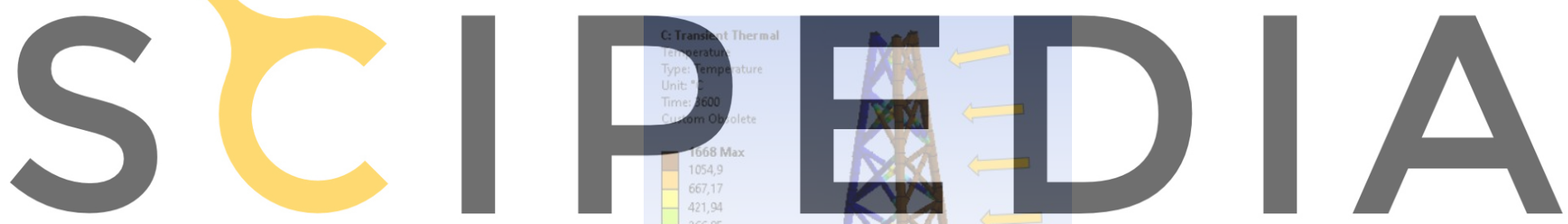

Register for free at https//www.scipedia.com to download the version without the watermark

Figure 18: ASTM B338 tube exhibition at 11:00 AM

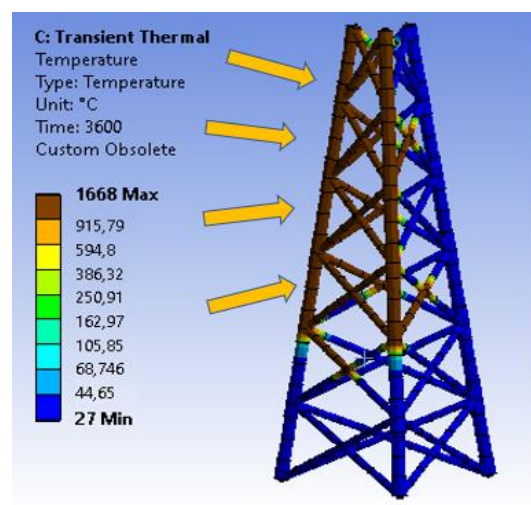

Figure 19: ASTM B338 tube exhibition at 04:00 PM 
At the end of each analysis, ANSYS organizes all the behaviour data of each tube into three categories: Results, such as minimum and maximum temperature; processing information, the time required for the analyses to be processed; density, capacity and thermal conductivity. Each category presents the main information acquired throughout the analysis by the software. Thus, (Table 5) and (Table 6) present the following results:

Table 5: Results of ASTM tubes in the period of 11:00 AM

\begin{tabular}{|c|c|c|c|c|c|c|c|c|}
\hline \multirow{3}{*}{ 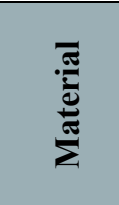 } & \multicolumn{8}{|c|}{$1^{\circ}$ Time-11:00 AM } \\
\hline & \multicolumn{5}{|c|}{ Results } & \multicolumn{3}{|c|}{ Constants } \\
\hline & Minimum & Maximum & Average & $\begin{array}{l}\text { Minimum } \\
\text { Occurrence }\end{array}$ & $\begin{array}{l}\text { Maximum } \\
\text { Occurrence }\end{array}$ & Density & $\begin{array}{l}\text { Thermal } \\
\text { Capacity }\end{array}$ & $\begin{array}{c}\text { Thermal } \\
\text { Conductivit } \\
\mathbf{y}\end{array}$ \\
\hline $\begin{array}{c}\text { ASTM } \\
\text { A36 }\end{array}$ & $27^{\circ} \mathrm{C}$ & $1410^{\circ} \mathrm{C}$ & $579,13^{\circ} \mathrm{C}$ & Tube $1-12$ & Tube 13-24 & $\begin{array}{c}7750 \\
\mathrm{~kg} \mathrm{~m}^{\wedge}- \\
3\end{array}$ & $\begin{array}{l}480, \mathrm{~J} \\
\mathrm{~kg}^{\wedge}-1 \\
\mathrm{C}^{\wedge}-1\end{array}$ & $\begin{array}{c}18,1 \mathrm{~W} \mathrm{~m}^{\wedge}- \\
1 \mathrm{C}^{\wedge}-1\end{array}$ \\
\hline $\begin{array}{c}\text { ASTM } \\
\mathbf{A 5 7 0}\end{array}$ & $27^{\circ} \mathrm{C}$ & $1510^{\circ} \mathrm{C}$ & $619,05^{\circ} \mathrm{C}$ & Tube $1-12$ & Tube 13-24 & $\begin{array}{c}7750 \\
\mathrm{~kg} \mathrm{~m}^{\wedge}- \\
3\end{array}$ & $\begin{array}{l}480, \mathrm{~J} \\
\mathrm{~kg}^{\wedge}-1 \\
\mathrm{C}^{\wedge}-1\end{array}$ & 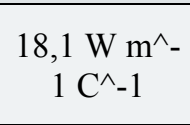 \\
\hline $\begin{array}{c}\text { ASTM } \\
\text { B338 }\end{array}$ & $27^{\circ} \mathrm{C}$ & $1688^{\circ} \mathrm{C}$ & $683,71^{\circ} \mathrm{C}$ & Tube $1-12$ & Tube 13-24 & $\begin{array}{c}4620 \\
\mathrm{~kg} \mathrm{~m}^{\wedge}- \\
3\end{array}$ & $\begin{array}{l}522, \mathrm{~J} \\
\mathrm{~kg}^{\wedge}-1 \\
\mathrm{C}^{\wedge}-1\end{array}$ & $\begin{array}{c}21,1 \mathrm{~W} \mathrm{~m}^{\wedge}- \\
1 \mathrm{C}^{\wedge}-1\end{array}$ \\
\hline
\end{tabular}

Table 6: Results of ASTM tubes in the period of 04:00 PM

\begin{tabular}{|c|c|c|c|c|c|c|c|c|c|c|}
\hline \multirow{3}{*}{ 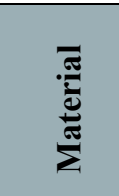 } & \multicolumn{10}{|c|}{$2^{\circ}$ Time - 04:00 PM } \\
\hline & \multicolumn{7}{|c|}{ Results } & \multicolumn{3}{|c|}{ Constants } \\
\hline & Minimum & Maximum & Average & $\begin{array}{l}\text { Min } \\
\text { Occu }\end{array}$ & $\begin{array}{l}\text { um } \\
\text { ence }\end{array}$ & $\begin{array}{l}\text { Ma } \\
\text { Occ }\end{array}$ & $\begin{array}{l}\text { imum } \\
\text { rrence }\end{array}$ & Density & $\begin{array}{l}\text { Thermal } \\
\text { Capacity }\end{array}$ & $\begin{array}{c}\text { Thermal } \\
\text { Conductivity }\end{array}$ \\
\hline $\begin{array}{c}\text { ASTM } \\
\text { A36 }\end{array}$ & $25^{\circ} \mathrm{C}$ & $1410^{\circ} \mathrm{C}$ & \multicolumn{2}{|c|}{$539,03{ }^{\circ} \mathrm{C}$} & \multicolumn{2}{|c|}{ Tube $1-12$} & $\begin{array}{l}\text { Tube } \\
13-24\end{array}$ & $\begin{array}{c}7850 \\
\mathrm{~kg} \mathrm{~m}^{\wedge}- \\
3\end{array}$ & $\begin{array}{c}480, \mathrm{~J} \\
\mathrm{~kg}^{\wedge}-1 \\
\mathrm{C}^{\wedge}-1\end{array}$ & $\begin{array}{c}60,5 \mathrm{~W} \mathrm{~m} \mathrm{~m}^{\wedge}-1 \\
\mathrm{C}^{\wedge}-1\end{array}$ \\
\hline $\begin{array}{c}\text { ASTM } \\
\text { A570 }\end{array}$ & $25^{\circ} \mathrm{C}$ & $1510^{\circ} \mathrm{C}$ & \multicolumn{2}{|c|}{$632,14,05^{\circ} \mathrm{C}$} & \multicolumn{2}{|c|}{ Tube $1-12$} & $\begin{array}{l}\text { Tube } \\
13-24\end{array}$ & $\begin{array}{c}7630 \\
\mathrm{~kg} \mathrm{~m}^{\wedge}- \\
3\end{array}$ & $\begin{array}{c}500, \mathrm{~J} \\
\mathrm{~kg}^{\wedge}-1 \\
\mathrm{C}^{\wedge}-1\end{array}$ & $\begin{array}{c}21,1 \mathrm{~W} \mathrm{~m}^{\wedge}-1 \\
\mathrm{C}^{\wedge}-1\end{array}$ \\
\hline $\begin{array}{c}\text { ASTM } \\
\text { B338 }\end{array}$ & $25^{\circ} \mathrm{C}$ & $1688^{\circ} \mathrm{C}$ & \multicolumn{2}{|c|}{$678,71^{\circ} \mathrm{C}$} & \multicolumn{2}{|c|}{ Tube $1-12$} & $\begin{array}{l}\text { Tube } \\
13-24\end{array}$ & $\begin{array}{c}4620 \\
\mathrm{~kg} \mathrm{~m}^{\wedge}- \\
3\end{array}$ & $\begin{array}{c}522, \mathrm{~J} \\
\mathrm{~kg}^{\wedge}-1 \\
\mathrm{C}^{\wedge}-1\end{array}$ & $\begin{array}{c}21,9 \mathrm{~W} \mathrm{~m}^{\wedge}-1 \\
\mathrm{C}^{\wedge}-1\end{array}$ \\
\hline
\end{tabular}

According to the obtained data, were compared the coefficients of density, capacity and thermal conduction of the materials, at the two times previously determined. Thus, which ASTM tube resists the thermal effects on the structure. The density of a tube refers to how much the thermally dilated material can weigh in a given space.

As shown in (Graphic 1), the STRUCTURAL TUBE ASTM B338 presented better results compared to the other materials, proving that tubes with titanium alloys in their composition make the material lighter and contribute to the reduction of the contact surface with other components present in the structure. The steel and carbon steel tubes tend to weigh more, because of their composition of minerals and chemical elements iron and carbon, in relation to the titanium tube which is composed mainly of titanium and copper, being a much lighter tube than the other. 


\section{CONCLUSIONS}

Given that it is inevitable that any metal structure suffers from the effects of solar charges and external thermal charges, the purpose of thermal analysis is to identify the efficiency of tubular materials available on the market in the design of self-sustaining towers in the urban environment.

Over the years, the temperature of the earth and the thermal sensation are constantly increasing, so metal structures that are exposed in the urban and rural environment are subject to suffer more from the long exposure of solar radiation. Currently, the current self-generating metal structures suffer from the consequences that solar radiation can bring, thus generating structural problems, material degradation of the structure and reduction of the life of the same. ANSYS, because it is a software with a huge database, has more accuracy in its results and demonstrates time savings and requires fewer resources, to solve problems such as thermal wear.

To arrive at the results of the analysis of density, conduction and thermal capacity, the software performed a series of repetitions until reaching a certain solution, thus demonstrating more reliability in the results exposed by it.

By the results of the analyses performed, the ASTM A36 and A570 tubes suffer more from the effects of solar radiation, thus causing more ease to thermal wear and decreasing the material's useful time, different from the ASTM B338 tube that present better results in conduction of heat loads and lower thermal expansion. Certainly, the tube becomes an alternative in the market, which, consequently, makes room for new materials that may in the future be more efficient and less aggressive to the environment.

\section{REFERENCES}

[1] A Conceição Machado. Characterization of aerodynamic properties of metal towers to determine the due response to wind, 2003.

[2] ARGYRIS, J. H. Reasoning, learning and action: Individual and organizational. Sociology Mind, San Francisco, CA, Vol.3 No.1, January 28, 2013

[3] ANSYS, Inc. ANSYS 19.0 Complete User's Manual Set. 2017.

[4] BRASIL, R. M. L. R. F.; SILVA, M. A. RC large displacements: Optimization applied to experimental results. Computers and Structures, v 84, p $1164-1171,2006$.

[5] BROWN, M.E. Introduction to thermal analysis: techniques and applications. London: Chapman and Hall, 1988. p.1.

[6] CAMMENGA, H.K.; EPPLE, M. Basic principle of thermoanalyticasl techniques and their applications in preparative chemistry. Angew. Chem., Int. Ed. Engl., Weinheim, v.34, n.11, p.1171-1187, 1995.

[7] ERDOGAN MADENCI, IBRAHIM GUVEN. La méthode d'élément fini et l'application dans l'ingénierie en utilisant ANSYS. 2015.

[8] STRATASYS, DIRECT MANUFACTURING. Access in September, 15, 2019. 